Portland State University

PDXScholar

\title{
How TRIO Sparked the Fire That Fuels the First- Generation Movement: An Interview With Arnold Mitchem and Maureen Hoyler
}

\author{
Rashné Jehangir \\ University of Minnesota \\ Lindsay Romasanta \\ Portland State University, lindsay.romasanta@pdx.edu \\ Arnold Mitchem \\ Council for Opportunity in Education \\ Maureen Hoyler \\ Council for Opportunity in Education
}

Follow this and additional works at: https://pdxscholar.library.pdx.edu/president_diversity_pubs

Part of the Education Commons, and the Social Justice Commons Let us know how access to this document benefits you.

\begin{abstract}
Citation Details
Jehangir, R. R., \& Romasanta, L. (2021). How TRIO Sparked the Fire That Fuels the First-Generation Movement: An Interview With Arnold Mitchem and Maureen Hoyler. Journal of First-generation Student Success, 1(1), 3-19.
\end{abstract}

This Post-Print is brought to you for free and open access. It has been accepted for inclusion in Global Diversity and Inclusion Publications and Presentations by an authorized administrator of PDXScholar. Please contact us if we can make this document more accessible: pdxscholar@pdx.edu. 


\title{
How TRIO Sparked the Fire That Fuels the First-Generation Movement: An Interview With Arnold Mitchem and Maureen Hoyler
}

\author{
Rashné R. Jehangir \& Lindsay Romasanta
}

The Co-Editors of this journal, Rashné R. Jehangir, Ph.D., and Lindsay Romasanta, Ed.D., both former TRIO staff members, begin this inaugural issue with an interview with Council for Opportunity in Education founder and president emeritus Arnold Mitchem, Ph.D., and current president Maureen Hoyler, J.D. This conversation is an effort to situate the history of the first-gen movement with those who were there at the beginning and continue to engage in the work today. To quote James Baldwin, "Know from whence you came. If you know whence you came, there are absolutely no limitations to where you can go."

The term "first-generation" has grown in use over the past ten years and has its roots in the Higher Education Act of 1980. In 2017, the Council for Opportunity in Education (COE) and the Center for First-generation Student Success (Center) launched the inaugural FirstGeneration College Celebration to encourage colleges and universities to celebrate the success of first-generation college students, faculty, and staff. This coming together of COE and NASPA was the impetus behind the idea for this interview.

This interview was conducted by video conference on December 10th, 2020, and has been edited for space and context.

Dr. Rashné R. Jehangir (RJ): Today, we have the privilege of interviewing Dr. Arnold Mitchem and Maureen Hoyler; two people who we think of as the roots of TRIO programs but also [as] gardeners who have long tended the TRIO tree as it has grown and prospered through these uncertain times. We're really excited for this conversation today. And the first question is really a question I know people are interested in, which is to share a little bit about your own careers in TRIO and the foundation and creation of the Council for Opportunity in Education (COE).

Dr. Arnold Mitchem (AM): I began my professional career at Marquette University on the history faculty and later became the Director of the University's Educational Opportunity Program. Under pressure from students involved in Civil Rights protests, in the Spring of 1968, the university had agreed to establish special scholarships and supports for minority students. When I was hired the university had named its "support program," the Special Program for Culturally Distinct Students, but I quickly moved to change the name to the Educational Opportunity Program (EOP). But anyway, that started in January of 1969 when I began to recruit the first class of EOP students. While EOP was initially funded totally with university funds, we brought in our first TRIO grant in 1970; the Student Support Services grant. And that was my introduction to TRIO. The key thing here is that Marquette's EOP was already doing all of the functions that the federal government had expected and outlined in their proposal request, so it was an easy transition for us. I think it's important to stress that the ... Marquette program really started with Marquette funds, which later gave me the flexibility and the resources to do the organizing and the lobbying, the advocacy in Washington, D.C., and so, I and whoever followed me were very fortunate in that regard. 
RJ: Thanks Mitch, I hear your point about the role that institutions play in matching funds for TRIO programs and the necessity of this partnership and commitment. It is also interesting to see the language that was employed to describe TRIO students-- "culturally distinct" - and the historical role that language has in perpetuating a deficit narrative about first-generation college students. Before we dig into that can you say a little bit more about the formation of the Council of Opportunity in Education itself and your role in that?

AM: Sure. EOA (Educational Opportunity Association) was the second regional TRIO association and it originally included TRIO educators from Illinois, Indiana, Michigan, Minnesota, Ohio, and Wisconsin. It was formed in 1974 and I was elected its first President. I was able to use EOA as a platform to go out and encourage other TRIO educators around the country to also create professional organizations. And so, by 1977, we had roughly eight or nine organizations. Representatives of those regional associations met in New Orleans in December of 1977 and created a provisional national group and I was the "convener" of that group. As President of EOA, I had begun going to Washington on a fairly regular basis to represent the views of EOA's members with the Congress and the then Office of Education. So, that national group made a decision to continue our involvement in the higher education appropriations process, an involvement that began in 1977. We were also peripherally involved on the authorizing side-in the Education Amendments of ' 76 . So, the whole federal thing, I was the lead dog on all of that, met regularly with Congressional staff and testified before Congress in 1975, testified before appropriations subcommittees in '77.

Since we were late in organizing, we had limited involvement in changes made to the TRIO subpart of the Higher Education Act in 1976 and we resolved to have a much stronger role in the next reauthorization.

We got involved in the process to assure the views of TRIO educators were considered when Congress acted on the Education Amendments of 1980, which as you know, introduced the concept of the first-generation student. And so, I was the leader in all of those efforts. So from the point that I became the president of EOA in ' 74 , and then, the head of the provisional group in '77, and then later became the president or Executive Director of COE in 1981, I was there. Maureen of course, was by my side in most of those things all along. We opened the office in Washington in June of ' 81 . Dr. Monte Perez, the National Association for Educational Opportunity President, became the first Director of the Washington office. He was the person responsible for the office. He reported to me. I was still a volunteer, that is, I was a volunteer in terms of COE because my salary and all was coming from Marquette University. Maureen joined Monte on the Washington office staff in 1981 to open the office.

RJ: Thanks, Mitch. It is important to remember how the Educational Amendments of 1980 and the reauthorization of the Higher Ed Act of 1965 set the stage for so many integral parts of access to college ranging from the establishment of TRIO to the Pell Grants and SEOG and Work Study. And that you and Maureen are still there for TRIO and first-gen students in so many respects!

Maureen, can you share a little bit about how you entered into TRIO? Some of the story 
Mitch has shared, but I want to make sure you get to add things from your own perspective.

Maureen Hoyler (MH): I was a student at Marquette when Dr. Mitchem took over as Director of the Educational Opportunity Program (EOP). So, the first year that he was there, I actually was studying at Xavier University in Louisiana. It happened that when I came back to begin my senior year, I met a friend of mine and she said, "Oh, I'm helping set up this tutoring program for the Educational Opportunity Program and do you want to help?" I said, "Sure."

So, the story I tell is that there were four of us who met to assign tutors to the first class of Educational Opportunity students. EOP had already had a summer program and Dr. Mitchem and John Clark, who was a student hired to work part-time as the Tutorial Coordinator for the Educational Opportunity Program and a member of the Black Student Union at Marquette, had interviewed all the potential tutors. And so, it was just matching the students and the tutors. The four of us went through the rosters twiceand Mitch was not satisfied with the final matches either time, so we did it the third time. I was impressed with the thought and personal knowledge of the students Mitch put into the tutorial assignments-and I guess he was excited that I was still awake despite the lateness of the hour so Mitch offered me a work-study job with the program. After I graduated, I continued to work part-time for EOP until I joined the program staff fulltime in 1973.

RJ: This is an important history lesson and underscores a few really important things-first, the process by which a small group of committed individuals, to quote Margaret Mead, created the Council of Opportunity in Education which serves as a powerful lobby for first-generation, low-income students. And, second, the impact that early experiences in TRIO programs and higher education have had in shaping the career trajectories of many young people, including you, Maureen! It also reminds me how many of us fell into the work of equity and student affairs as undergraduates and what we as a field can do to create more avenues for careers in higher education.

AM: We put together a tutorial program where we pre-assigned tutors to the students. But we didn't wait for students to seek out tutors. We felt that the students would encounter significant academic challenges and we tried to keep them out of trouble as opposed to trying to rescue them later in the semester.

RJ: Intrusive advising, that's been at the core TRIO for a long time! The process you described about matching students embodies the necessity of tailoring programming to meet students' needs and the ethic of care involved in doing that right. So, you noted earlier, Dr. Mitchem, that the formulation of the term first-generation incorporated into the 1980 policy was something that came out of TRIO. Can you talk a little bit about the process and decisions to use the term, first-generation, within TRIO, and what you sought to encapsulate with that particular terminology?

AM: At the 1977 meeting of the provisional national group in New Orleans, it was agreed that TRIO educators should get involved in the Higher Education Act Reauthorization. Following that meeting, each regional association was asked to put together a set of recommendations and to bring them back to our next meeting, in Denver in June of ' 78 . And so, in the Midwest, we created task forces, one for Student Support Services, one for 
Upward Bound, and another for Talent Search and EOC.

The Student Support Services Task Force met at Indiana University and the EOA leadership had put together a series of questions that we asked each Task Force to address. One of the things we were struggling with was the eligibility criteria for students in TRIO. And there were different kinds of pressures. For example, in the Midwest, the income criteria that the Office of Education used was, from many of my colleagues' point of view, oppressive.

A family income that might be considered "adequate" in Kentucky or Mississippi was often insufficient to even minimally support a family in northern urban centers. So, that created difficulties. We also were disturbed by some of the language; culturally disadvantaged, for example, and the characterizations of our students, which we didn't like at all. And so, we're looking for more neutral, more positive language.

We also saw a philosophical and political imperative to accommodate all of the oppressed... the groups of color and also to include Whites; poor Whites. And so, we had to try to wrestle with all of these objectives, concerns, intentions. In the midst of this ... and then, one other pressure, we were also at this point interacting with the Appropriations Committees in the Congress. One of the questions that they always posed to me and others was, "Who's going to get the money? Who are you serving?" And so you're giving them this pablum, this ambiguous language about eligibility, which really amounts to anybody in the world, if you're "culturally deprived" or what have you.

To address the eligibility question, a Director by the name of Don Gillies, who I believe was from the University of Iowa, and who had recently migrated from somewhere in California, said, "Hey, here's a concept ... first-generation." And so, we listened to him. He just laid it out. Now, not everyone liked that concept, first-generation.

However, EOA brought the first-generation eligibility recommendation to the National Task Force which met over the summer. Finally, in Portland, Oregon, in September of 1978 the Portland Task Force came up with what they called the Portland Compromise. That was the language that combined income and parents' education into the eligibility criteria for TRIO. Many argued, "We just can't move away from the economic indicator, low-income," that's sacrilegious, that's blasphemy. So, while there is some variation by TRIO program, eligibility is consistent that in all programs two-thirds of the students served must be both low-income and first-generation students. (However, the low-income definition was raised from $100 \%$ of the poverty level to $150 \%$ of the poverty level.)

The Task Force left Portland, and at the meeting of the entire national group in Arlington, Virginia, in December 1978 the Task Force recommendation on "first-generation" was adopted. Our recommendations had been requested by Democratic Congressman William Ford of Michigan who chaired the House of Representatives' Subcommittee on Postsecondary Education. As the Subcommittee requested, we "translated" those recommendations into legislative language and, I think, in February of 1979 submitted them to the Subcommittee. Maureen can talk a bit about that because she took the rhetoric and translated it into legalese. I think you had just graduated from law school... 
MH: No, I was still in law school.

AM:... Oh, you were still in law school. She had the benefit of working with a real great guy named-

MH: Richard Smith.

AM: . . Richard Smith, yeah, who had been involved in drafting the Pell Grant language. Richard worked with Senator Pell of Rhode Island, and he was a friend of mine and so forth and so on. And so they worked together. So anyway, that legislative draft was incorporated in H.R.5192, that was the House bill. So here we are. You have these fledgling organizations under this label, National Coordinating Council of Education Opportunity Associations becoming the voice of TRIO, so to speak. But everybody didn't agree with the Coordinating Council's recommendation on first-generation eligibility. In fact, two associations, the Southwest Association and the Northwest Association initially did not sign on. It was only literally hours before we testified before Congress in April of 1978 that the Southwest Association signed on, but the Northwest Association never did. So anyway, there were a lot of debates about first-generation in TRIO communities.

The Senate Subcommittee on Education accepted all of the language the Coordinating Committee had submitted to the House and utilized that language in their bill S.1839. The House and Senate conferenced their versions of the bills. The final result is the Education Amendments of 1980 was signed into law by President Carter at Northern Virginia Community College in October of 1980. That's where the ceremony was held and boom! We go off running. And then, Ronald Reagan got elected a few weeks later and tried to destroy all of it. But anyway, that's how we got here.

RJ: Wow. As I have said before, listening to the two of you talk is better than watching the best episode of West Wing. You unpack the political context of that time and necessity to make compromises and the ongoing concerns with how first-generation was defined. We are in a different place and time now, and yet some of these concerns persist. In particular, we still must grapple with reading and negotiating the political context both on our campuses and nation-states and how we complicate the term first-generation.

MH: Yes, it's probably important to say that two people were really critical in the Coordinating Council being invited to submit the language. One was, as Dr. Mitchem said, Bill Ford, who was Chairman of the Subcommittee on Postsecondary Education. And he was himself first-generation. The other key individual was the Staff Director who really engineered the process. Today, if you were going through a reauthorization of the Higher Education Act, there'd be no request for written recommendations. There would be none of this kind of constituent input. There would be some constituent input, but nothing like there was in 1980. And that Staff Director was Dr. Thomas Wolanin, also from Michigan.

And he, too, was first-generation. So, that touched a chord with both of them, that language. And part of what they did in 1980 and in subsequent reauthorizations was trying to get rid of any negative words like Mitch 
mentioned, "culturally-disadvantaged" or "rurally-isolated." They tried to get that kind of language out of the TRIO subpart. And as Mitch said, we transferred the recommendations into legislative language and they accepted the legislative language as we wrote it without change. Which, when you think about it, is amazing citizen input into how legislation is written.

AM: We really objectified the criteria; remove it from totally subjective to objective. We pegged income to the Bureau of Labor Statistics. So we didn't want any ambiguity. We wanted to be very clear and so we got it.

MH: As Mitch mentioned, in 1980, there were four TRIO programs, and they all have slightly different mixes of low-income and first-generation. So, Upward Bound, two-thirds had to be low-income and first-generation and one third either/or. In Student Support Services, the retention program, two thirds had to be low-income, first-generation, or students with disabilities and one third had to be one of the three.

In Talent Search and EOC, two thirds have to be low-income and first-generation, but the other third didn't have to meet any named criteria in the subpart because they wanted the programs to go out and get as many low-income, first-generation students as they could and they didn't want them to have to lead with, "Well, did your parents go to college?" or "How much does your mama make?" So they left that one third deliberately open and that still is the basic framework in the eligibility today.

The other reason that Congress adopted first-generation, and I think it was part of the reason that Don Gillies argued for it and later Fuji Adachi, who was at the University of Wyoming. He did a lot of the groundwork in terms of statistical backup, was that those are the two factors that are most correlated with college graduation: parents' income and parents' education. And so it wasn't just an attempt to come up with something that was more politically acceptable, it was the two criteria that are most predictive of whether a young person or an adult with further educational aspirations is going to get a college degree.

RJ: Thank you both for that. It is so powerful to hear about this journey and to recognize how first-gen representation in Congress shaped a window of opportunity and understanding that you were able to tap into. Just a quick follow-up to that, the language that Kimberlé Crenshaw has brought into the academy from her legal work around intersectionality has become a commonplace in higher education in a way that it wasn't before. And when I hear about the grappling of this language, I'm hearing that there were tensions around inclusion of race, level or type of income that constitutes poverty in various states, and disability, and the intersection of these identities. Is that a fair assessment? And do you feel like TRIO still encapsulates those populations as it seeks to engage in upward mobility?

MH: Let me take a crack at this and then Mitch, I think you can probably answer better than I. What these two criteria, income and parents' education, allow is for advocates on the ground to push for outreach and supportive services for those who most need the services. The reason there is a set of federal programs is that too many times students from particular groups are not welcomed by colleges and universities. I say many times to TRIO people, if 
Congress thought that low-income and first-generation students were being sought out and embraced and supported by the academy, there wouldn't be a need for a federal role.

The federal government recognizes that it's going to be a fight to get these students truly included. And the face of that student may be different in Kentucky than it is in California, than it is in Minnesota. So, the advocates have to be conscious of being true to the Civil Rights history of the programs and at the same time, to the needs of their communities, and the needs of their institutions. There may be particular groups of students that some colleges are not serving, and TRIO programs need to make sure that they meet student need, institutional need, community need, and that's always going to be a fight. I mean, it's not just, "So we got this grant and now we can serve all these" ... People just don't agree to serve the students that have been historically excluded automatically. It always involves advocacy, it always involves pressure, and it always involves leadership.

AM: One thing I can add to that is that you can see the tension between poverty and disability. Though, that sprung up in one of the reauthorizations because we discovered that in certain parts of the United States, in areas where there were very few people of color, let's take Northern Wisconsin or Maine or New Hampshire, that programs rather than work or seek poor whites would build TRIO Student Support Services just for students with disabilities, primarily middle- and upper-income students with disabilities.

At the time that this became an issue, it turned out that many of these students were "learning-disabled." And also, some people argued that some of these "learning-disabled" students weren't as disadvantaged as let's say, a blind student would have been, or a student in a wheelchair, and so forth and so on. But anyway, some people felt there was some scamming going on, there were the middle-class parents pushing students who, "Well, Johnny can't do this or that." And some of these cases are real and this assumption was unfair, I'm sure, but on the other hand, it appeared that at a number of our institutions, they would rather serve "students with disabilities" than poor white students or students who look like me (i.e., students of color).

MH: So, the compromise, and we came to this compromise with the organizations that represented individuals with disabilities, was that a third of the students with disabilities that were served by TRIO Student Support Services had to be low-income. The advocacy groups representing individuals with disabilities had also found that low-income students with disabilities were very underrepresented in colleges. So, again, it was looking at what institutions were doing and not doing to support individuals that didn't have a fair chance of entering and graduating.

In a way, it was kind of unfair. Institutions had a legal responsibility to provide accommodations for students with disabilities, but they had no legal responsibility to provide accommodations for low-income students. So, given the pressures on them, they chose to serve the group that had the legal protection. So by changing the eligibility criteria slightly, we were able to balance those needs.

RJ: Thank you, thank you both. Part of what you're talking about is the nuance of context and place that shifts depending on the institution, on the state and so on, and that's really 
helpful to have articulated and leads into the third question. This question speaks to the way I think some of these ongoing tensions around race and social class and disability continue to be debated in higher education. And we're now at a place where we have National First-gen Day, and we have celebrations across campuses in the United States in a way that I couldn't have imagined 20 years ago.

And there's a small part of me that feels like, "Hey, we've been shouting about this for a long time. It's great that you're finally on board, but hey, we've been shouting about it." So, one of the things that has emerged in this work for many of us is that people are critiquing how institutions are employing "first-generation" as a proxy, a loose catch-all without attention to the historic constraints of racism and classism. What advice might you have for administrators and change agents in how they employ and embed first-gen language in their policies and practices so as to attend to what is really underneath these identities?

MH: Yes, I think it's very true. And the term can be misused. The term can be, "Oh, let's celebrate first-generation students. So, we're going to count the number of first-generation students ... but we're not really going to change who we are as a campus." The term was introduced to promote change and to produce equity and to produce a recognition of individuals' potential that may not have had their potential recognized without the term. I was delighted that in that session that NASPA sponsored that we were able to show that little clip of President Biden, who talked about the potential of first-generation students that would otherwise go unrecognized. I mean, would President Biden, who was a first-generation college student, be president today if he didn't go to college? It is very unlikely.

If we don't invest in individuals who are first-generation-regardless of race, regardless of income--and provide assistance and support, their potential is often unrealized. But we cannot ignore the additional barriers of race, ethnicity, class, and disability. And that's what TRIO's about. That's what the federal role in higher education is about. It's important always that the advocates for first-generation students on campuses remember that Civil Rights history and make sure that the terms aren't being perverted.

AM: I mean, colleges play, Rashné, the game that you've described all the time. But I think the only add, though, is the terms on our educators, the TRIO Directors there, that they have to challenge it. I don't see any other way to get around it. They have to get in their face and say, "No, this isn't appropriate." And I don't see any way to substitute for that. Because colleges do it. I mean, I've seen it over and over.

MH: And I think, too, the role of partnering with faculty; for example at COE, we just had a symposium that was led by Shaun Harper at USC and Waldo Johnson from the University of Chicago, who was a TRIO alum, and faculty. We had over 75 individuals most of whom were TRIO alums who are currently faculty in colleges and universities. They too have a special role in making sure that institutions are supportive and hospitable to low-income and first-generation students and students of color.

They've had to go through, in most instances, very isolating experiences to get those Ph.D.'s. 
And sometimes, had to jump through hoops that they should not have had to jump through. Clearly, there's hoops they should have had to jump through; the skills they should have had to demonstrate, knowledge etc. ... But oftentimes, they've had to demonstrate things that have nothing to do with competency. And so, the faculty play a hugely important role in changing the face of higher education as it looks to individuals that have been excluded or have been given half a chance; given access to our least-resourced institutions, but not to our most highly-resourced institutions, given access to institutions, but no support when they get there. So, this is a shared responsibility.

RJ: Thanks, Maureen. Yeah, between March and May of this year, I just completed a study on first-generation college students who are now in graduate school, and I'm compiling the data right now. These students have extremely nuanced, complicated understandings of where they're positioned in higher education. And one of them said: "I'm living in the gap and there are ways in which the system actively restricts sunlight." That's the way he framed it-restricting sunlight. I thought that was just not only poetic, but brilliant and also so frustrating to hear. So, that is an area of research, mentoring that needs much more attention. You are so right, it is something that will create more soldiers in this work that we're trying to do, so I appreciate you saying that.

Dr. Lindsay Romasanta (LR): Thank you so much, Maureen and Mitch. This interview has been very illuminating. We would like to get your take on the impact of the pandemic, and the collective, ambiguous loss many of our students and our communities have faced. Many first-gen champions and educational leaders are reconciling that the pandemic and the political unrest we have experienced will have a lasting impact on higher education. How do educators and thought leaders strategically foster commitment and accountability towards first-generation student success even while we're being faced with the possibility of being asked to do more with less?

MH: First, let me say that the biggest declines, the biggest losses have been among low-income and first-generation students and underrepresented students. Those are the individuals that have been bumped out of the pipeline to college and the pipeline to college graduation. I haven't seen the numbers that reflect losses in graduate education, but I can't help but think that it will be true there as well. And so, one of the things that those who advocate for low-income, first-generation students, students from underrepresented groups have to make clear to their institutions is that the solution is in these students.

You know, there's a lot of people who think that there are enough traditional students to go around and if their institution could just get the kind of kids they had 20 years ago or ... But they're not there anymore. And so, the solution is in these low-income, first-generation and underrepresented students. And so, as you have said, and NASPA has, we have to create institutions that are ready to support these students and realize that they have to be or that many colleges' financial futures are really in question now.

I was on a really interesting presentation this morning that talked again about state disinvestment in higher education. It's a huge question. If we can't get states to reinvest 
in our students, then the federal government doesn't have the whole solution. There's no clear way to see an end to this. So, we have to hone our advocacy skills. We have to represent our students, not just by providing services, but by creating groups that can fight; that all students have a realistic chance to earn a college degree.

AM: That's really a critical point. Lindsay, where you are in California, the great shame is, if you go back, oh, God, I guess you got to go back maybe 50, 60 years, higher education was basically free in your state. Community colleges, the CSU system, etc. And that empowered the old generation to vote. But as the demographics began to shift, particularly as Latinos became a larger share of the population, 30, 40 years ago, the fees started creeping in. And I don't know what situation is like in California today, but it's certainly not friendly, I suspect ...

LR: Yes, California also still has a long way to go in ensuring higher education support for our low-income, first-generation college students. We also face challenges in seeing progressive pieces of legislation that could impact educational access opportunities for our minoritized, first-generation student population. In the November 2020 election, California voters had an opportunity to repeal the ban on affirmative action through Prop 16, but this did not pass leaving the ban on affirmative action in place.

LR: . . Yes, over $57 \%$ of voters voted no on the measure, so now, California higher education leaders and institutions are faced with the fact that without changes in legislation, we will continue to face challenges in diversifying our student body to reflect California. In JOURNAL OF FIRST-GENERATION STUDENT SUCCESS 13

response, institutions are considering and proposing new terminology that is race-neutral yet signals the underrepresented populations that are still experiencing access issues to California public institutions.

One of those pieces of terminology is called "new-gen." And in this new-gen terminology, they're really trying to pay attention to underserved students, underrepresented minority students, and also first-gen and Pell, which is important. But this is also somewhat problematic as they are not looking at disaggregated data. For example, without data disaggregation they are missing groups of student populations who are also largely underrepresented on our college campuses, for example, Hmong students or Laotian students. Instead, they are being lumped in a potentially misrepresented category using a terminology such as new gen. What are your thoughts when even seemingly diverse and progressive states such as California fail to pass legislation that could be transformative for our first-generation and minoritized students?

MH: Nobody said it would be easy. Nobody said it would be easy. And those who have benefited from higher education and have children, of course, they want their children to have the same benefits. So, when we look at opportunity as a zero-sum game, you can't win a zero-sum game, nobody can win a zero-sum game. That's one of the reasons first-generation is an attractive concept, because in Maine or in Idaho, or in Utah, people know hard-working first-generation students who they believe need extra support. There is something about first-generation that brings people together. 
And as you said, when in a place like California rejects race and ethnicity as a criteria, there's other criteria. There's zip codes and income and matching zip code and income and luckily, people in higher education are smart, and if they want to achieve greater equity, income alone won't do it, first-generation alone won't do it, but there are ways, at least many would argue that there are ways to achieve the goal by focusing on those students who most need access and support.

AM: Yeah, I was just going to say, and Frederick Douglass, the first Black lobbyist said, it's all about struggle. And so, it just goes on and on and on, and layers of resistance to try to make a more perfect union, including progressive California.

RJ: I was reading an interview and in The New Yorker this morning with President Obama, and he was talking about this notion of language. And the key is deciding, do you want to actually get something done? Or do you want to feel good among the people you already agree with? And I thought that is so inherent to the struggle of our work; the negotiating language and nuance and figuring what language to use with which audience to propel what you need to propel forward while still irritating some other people. It seems to be at the core of what we're trying to do. It's hard.

MH: Yes, there's another great article out yesterday. I think it's yesterday, in The New York Times that talked about status, and how, like other resources, status is a value; it is very much valued by people. And when those of us associated with higher education communicate that we have a status that is higher than those who haven't had a higher education, we create division. And I think there's a lot in that whole issue of status and respect, that we have to really work on.

I once was having a conversation with the dean at a prestigious, four-year public university and he said, "Well, faculty are not that much smarter than anybody else, but what distinguishes them is that they're able to concentrate on a very minute portion of a discipline and devote their lives to that small question or area. And that ability to focus does make it harder to be political because if you're narrowly focused, it's harder to create coalitions and see the other's perspective." So, that's always informed me. I think higher education is a harder space to bring people together to be advocates.

RJ: Thanks, Maureen. This notion of being political is one that is vital-it is another key lesson from TRIO--that advocacy, coalition building, and allyship moves from how we work with individual students, to partnerships across siloed programs in higher education, and with our states with an eye toward both practice and policy. One of the things I was thinking about from early in the interview was the way in which Mitch talked about the use of terms like "culturally-distinct" and then other forms of deficit-based characterizations of groups of students that we're seeking to support. And it kind of ties in with what you just said, Maureen-the idea that there is an inherent and often implicit condescension that higher ed has for people who are not of it, including the families of our students, which doesn't work so well. It doesn't help to make people feel like where they came from isn't valuable and important. 
So, one of the things I've been thinking about, and Lindsay and I both have talked about this a lot, is the growing potential to attend to the capital first-gen students bring to higher ed. First-gen students are in a place now, at least in the last 10 years, where they are gaining visibility and can claim some of the cultural wealth that they bring to the academy, whether it's navigational capital or language or code-switching, all those kinds of things; they're bringing that into the sphere. So, what advice would you give our students, undergraduates and graduates to become politically and socially engaged?

AM: That's a tough one. It's a perennial question, isn't it? I mean, it's going on and on and on. I guess the first thing is to recognize that which disturbs, bothers you or are obstacles to you also disturbs other people. You have to recognize that you can't change it by yourself, that you have to identify like-minded folk, that you have to organize, that you have to network. As an old Jesuit said to me 100 years ago, he said, "Mitch, you have to have an army." .. "You've got to go out and get five men [sic] and have each of those men go out and get five men, and all of you all together bring about whatever change that you feel is appropriate."

So it's all in organizing and persuading people and trying to find ways to create sustainability. You have to continue, and you get that there's no one great speech or one great vote. As I used to tell, there are no final victories in politics; it goes on and on and on. So, these are some of the values, insights, perspectives that people have to adopt, internalize and actualize if indeed, they are really interested in promoting change. It's tough. It's tough. The last thing I'd say is don't let your ego get in the way. Find some organization or association that is approaching some of the concerns or whatever it is that bothers you and join them, make them stronger. You don't have to create the answer, and you probably can't anyway. But you need people, a network, and you have to sustain it. And if you don't understand those things, you'll just be unhappy.

MH: The other thing that is frustrating is that you want to give people access to higher education, to a degree and access to mobility. And that means that they have choices. They have choices they would not have had, had they not had that opportunity. Some of them were going to choose to use those opportunities in ways that restrict opportunity for people behind them. Some of them are going to choose to ignore all the assistance they got to get where they are. But that's because you're giving people options. You have to recognize that that's part of the game. Most TRIO alum now, for example, are more than willing to say, "Hey, it was this counselor. If I hadn't had that information, if it wasn't this ..." But some of them don't even want to be associated with the term first-generation. They don't want to remember who they were. That's their right and their choice. That's a choice that they wouldn't have had if they hadn't gone to college and graduated.

RJ: Thanks for those comments Maureen. And my hope is that as we challenge the deficit narratives around this, more students will want to come forward and speak to that. I certainly have heard it in my research with students who sometimes feel like they choose very intentionally where and when to disclose their first-gen identity relative to their more visible identities as BIPOC scholars, because they feel like the social-class component is demeaned in higher education at the core. 
MH: Mitch and I have slightly different recollections about the origins of the McNair Scholars Program. But my recollection was that we were joined in our fight to get the McNair program funded and/or authorized in 1986 by the American Association of Universities (AACU). And they very much embraced the concept of both income and race and ethnicity as eligibility criteria But they were concerned that the students that didn't have the benefit of parents that had gone to college could actually excel in research and achieve faculty status. I'm sure you have noticed it in a number of discussions where just like you said, people are less open to disclosing their class and family backgrounds, but they can't not disclose their race or ethnicity. Because there are so many of the elite that question or appear to question the potential of low-income and first-generation individuals.

AM: Going back a bit, when we were fighting to get first-generation into the law, H.R.5192, there were two institutions in Southern states that opposed the concept. They argued that they couldn't educate, "minority students who were first-generation." And of course, they were speaking specifically of Black students. They said they needed Black students whose parents had gone to college, gotten a bachelor's degree, and mama or daddy was the schoolteacher. But to go to the ghetto of that was a no-no. There was another university, they weren't as articulate, but they said, "No," they didn't want first-generation students, that it was just a bad notion.

MH: I mean, if you go back several decades, but probably all of you are more familiar with this history than I am, a number of prominent institutions opposed the G.I. Bill for similar reasons.

LR: Thank you for sharing that Maureen and Mitch. It's quite evident the many years of structural barriers and opposition that have been placed upon the first-generation community, and we're so grateful to have you share your oral histories with us. Over 50 years later, we are still seeing similar struggles, but just in different forms. So many first-generation champions out there would be inspired to hear though, what is your most audacious vision for first-generation student success?

MH: Well, I think the mission and the vision statements of the Council for Opportunity and Education are audacious statements. It reads,

Mission: Achieve college access and success for low-income students, first-generation students, and students with disabilities.

Vision: Every young person and adult has an equal opportunity to prepare for, attend, and graduate from college. Graduation from any category of postsecondary institution is achievable and not limited by economic status, family background, or disability.

AM: Surely.

RJ: One other thing that you had mentioned when you talked about advocacy and pushing institutions when they used first-gen as a proxy, is that it rests with TRIO. One of the things that TRIO folk have shared with me is that sometimes on their own campuses, they don't have the capital, right? They still exist sort of on the periphery of the institution. And I wonder how non-TRIO first-gen allies and accomplices can work in solidarity with TRIO 
and on behalf of TRIO programs?

AM: Well, I think, both informally and formally, trying to articulate, one, the presence and value of TRIO programs, if they do exist on your campus. I think you're right, TRIO programs, almost by definition, because they're federal grants and in most instances, the institutions themselves haven't committed any resources to the programs, the Directors are really at a disadvantage. And many TRIO staff don't have doctorates and so they're not part of the club. And even if they did, they are still out there on this grant working with students who are perceived as marginal. And what does it mean? Why is it here or whatever? So, the short-term future for a lot of this doesn't look good.

I think the point that Maureen made at the meeting that she had recently where she pulled together a number of people who are now at institutions, TRIO people who have Ph.D.'s or are faculty, that's the army that's going to over time, change these assumptions. When those people, when you have more of them, when some of them are put in administrative roles and so on, and it's more of them, or some of them develop prestige because of their academic work, then their voice is louder.

AM: Because we're talking about prestige and resources. And it's just going to take a while. But that doesn't mean we say, "Oh, well, let's walk away." I think we try incrementally to do as much and whatever we can to create a space for these young people that we're bringing on these campuses that we're trying to empower and to provide opportunities that many of us have had-like the four of us looking at each other on the screen. And so we have a moral obligation to do everything we can in our lifetime and during our moment, to make that possible; not to be dissuaded or depressed by the social realities, but these are the realities. And some schools and places will get there before others will. And some will make no progress in 100 years or 200 years. But that's the reality, don't cry over that.

RJ: Thanks, Mitch, we're proud to be part of the army.

AM: It's an army for social struggle, for justice. I mean, it manifests itself in so many different ways. If there is any beauty to Donald Trump, he shone a light on all of it, and a whole generation of folk understand what people my age understood, because of our experiences. Now they see and know, and maybe a few of them, some of them, will pick up the cudgels and move forward to make for a better world. He's inspired people to fight. It's a struggle.

RJ: It is indeed a struggle. Is there anything that we didn't ask you that you want to make sure is in this interview or in this opening article in this issue?

AM: Well, here's one of the things that ... well, I know, one of the concerns that some TRIO people have is that "TRIO educators don't get any credit for inventing first-generation." I'm sure you've heard that rationale. I don't know how you address that. It's sort of like a lot of Black musicians back in the day talking about White folk not recognizing that they did the song first. I don't know what you do about that. But I think it's important somehow, to make the broader campus audiences cognizant of that feeling. I don't think it should be just the little minority secret that only we discuss.

Pardon my French, White folks need to know that that's out there and somehow, they need 
to figure out how to address it. And that will also, I would imagine, on the margins, help TRIO programs across the United States. I don't want to make a big thing out of it, but I think people need to be aware of that. And I think that NASPA as an organization needs to be aware of it. Because they don't want to get a Black guy over time to say, "Gee, these White folks came in and stole this concept and they wrapped it in White and boom! It's not a rainbow anymore, there's just snow again."

RJ: Yeah, I think that's very much been a conversation at NASPA and lots of other places. In fact, two years ago, I did a conference presentation at NASPA with my colleague, Dr. La'Tonya Rease Miles around this very idea that ...

AM: Really?

RJ: Yeah, we did a presentation around intentionally building partnerships between TRIO and non-TRIO allies and includes understanding the roots of where these things began and to recognize the expertise. A recognition that these are ideas that have allowed you to kind of breathe yourself into existence in other places.

And yet on the flip side, I think for folks who are not of TRIO, they can sometimes feel like, "Oh, you all are in a club and you think you all do it best and nobody else can do it as well as you." And so, there's that rub and trying to find a bridge between those two things is really important. So, I think the existence of the NASPA Center for First-generation Student Success and of this journal, I see as avenues to build those bridges. It is a very intentional creation of this rainbow coalition of people who, whether it's the folks on NASPA's advisory board for the First-gen Center, or our editorial board at the journal. It is indeed this real blend of people whose lived experience and expertise recognizes that. And that's a real joy to work around because you don't have to explain it all the time. It's there-that community cultural wealth is there to be tapped.

AM: I hope there's a lot of people there to follow you who bring your spirit and intellect to the work.

RJ: Thank you, Mitch-and yes, they are, there are. And with the people coming up now, the undergrads and grad students we see, it feels powerful. They are so smart, and they don't take nonsense. They don't suffer fools gladly.

AM: Ah! That's it. Good. I like that.

RJ: Well, I know we're over time and I am just so happy and honored to have this chance, Dr. Mitchem and Maureen, to be with you and learn from you.

AM: Well, I appreciate this opportunity too and please understand that.

LR: Thank you so much.

\section{Resources}


Council for Opportunity in Education - www.coenet.org

Center for First-generation Student Success - https://firstgen.naspa.org

Joint Virtual First-generation College Celebration - https://vimeo.com/477682433/

e71b6bcc65

Rashné R. Jehangir

University of Minnesota Twin Cities

jehan001@umn.edu

Lindsay Romasanta

University of California, San Diego

lromasanta@ucsd.edu 